\title{
Studies on Mechanical and Electrical Properties of Poly Carbonate-EPDM Blends
}

\author{
S Soundararajan* and K Palanivelu \\ Department of Plastics Technology / Central Institute of Plastics Engineering and Technology (CIPET), \\ Guindy, Chennai-600 032, INDIA
}

\begin{abstract}
PC (Poly Carbonate) was blended with EPDM (5\%-20\%) (wt\%) using a Twin Screw Compounding extruder. Test specimens were made by using an injection molding machine. The mechanical properties such as Tensile strength, Flexural strength were determined and found to be decreasing. The impact strength, Izod notched, was increased to about 200\%. The arc resistance was increased to about $300 \%$. Electrical properties such as Dielectric strength, Volume resistivity and surface resistivity were also improved.
\end{abstract}

Key Words: PC, EPDM, Twin Screw Compounding, Testing, mechanical and electrical properties.

\section{Introduction}

PC (Poly Carbonate) is one of the Engineering Thermoplastics and it has excellent impact strength due to its high intermolecular forces due to the polar Carbonate groups. $\mathrm{PC}$ has higher mechanical strength due to the presence of aromatic rings. Hence PC has high melting point $\left(245^{\circ} \mathrm{C}\right)$ and high $\mathrm{Tg}\left(145^{\circ} \mathrm{C}\right)$. But it is semiCrystalline nature and hence PC has only poor chemical resistance (1). Hence, it is desired to improve the chemical resistance, and also the impact resistance by blending with EPDM (Ethylene Propylene Diene Monomer) rubber which has low $\mathrm{Tg}$ ( about $-60^{\circ} \mathrm{C}$ ) depending upon type of Diene.

EPDM polymer (Elastomer) has excellent weather resistance, chemical resistance and oil resistance, lower water absorption and excellence electrical resistance (2). Hence, EPDM is widely used in Automotive application as blends with $\mathrm{PP}(2,3), \mathrm{PE}(4)$ or Nylons(5) and offers high impact strength and chemical resistance. These blends may be useful as Automotive interior \& under-hood components.

PC is also widely useful is Automotive applications like PC/ABS(6), PC/PBT, PC/PET (7) blends such as car bumpers; In PC/ABS blends, ABS offers good process ability and good chemical resistance. But lower the impact strength of PC, and the UV resistance. Hence, it is desired to improve the impact strength of PC by blending with EPDM and to study the mechanical, electrical and thermal properties of PC-EPDM blends.

\section{Experimental}

\subsection{Materials}

PC Trade Name Makrolon, 2858 of Bayer materials Science having MFI $10 \mathrm{gm} / 10 \mathrm{~min}$ is used in this study. EPDM trade Name Merlene, IM-7100 of Herdillia having MFI 5 gm\10 min is used.

\subsection{Methods}

Twin screw compounding

PC and EPDM Granules are mixed in a high speed mixer for 5 min and then melt blended using a Twin Screw extruder(Berstorff, FRG) of L/d $-33: 1$ and screw dia of $25 \mathrm{~mm}$. Twin Screw extruder offers better miscibility for making polymer blends and alloys. The Temp at different Zones are given below.

$\begin{array}{lcccccccccc}\text { Zones } & 1 & 2 & 3 & 4 & 5 & 6 & 7 & 8 & 9 & 10(\mathrm{Die}) \\ \mathrm{Temp}\left({ }^{\circ} \mathrm{C}\right) & 100 & 150 & 180 & 220 & 230 & 235 & 245 & 250 & 265 & 275\end{array}$

The Screw rpm is $150-200$.

The strands are cooled in a water trough and cut into granules.

\subsection{Testing}

Test specimens were prepared by using an injection molding m/c, SP 130 Windsor for the mechanical, electrical and thermal properties as per ASTM standards (8). The Tensile strength test was done using a UTM (Universal Testing Machine ) Lloyd, LR 100k as per ASTM D638 Type I specimen, using $50 \mathrm{~mm} / \mathrm{min}$ Test speed.The flexural strength was done as per ASTM D790, using the same UTM, with Flexure fixture.The Test speed is $2.8 \mathrm{~mm} / \mathrm{min}$. The Test specimen size $127 \times 12.7 \times 6.4 \mathrm{~mm}$. The Izod impact test is done by using Ats Faar $\mathrm{m} / \mathrm{c}$, Italy as per ASTM D256 Standards. MFI (Melt Flow Index) test was carried out as per ASTM D1238 standards using Lloyd(UK). The Volume and surface resistivity Tests are carried out as per ASTM D257 Standards using $110 \mathrm{~mm}$ dia disc with thickness $3-3.2 \mathrm{~mm}$. The Arc resistance was carried out as per ASTM D495 standard and the Dielectric strength Test was carried out as per ASTM D149 standard. 


\section{Results and Discussion}

The Test results are shown in the Table I \& II and in figures $1 \& 2$, for the Mechanical, Thermal and Electrical properties.

Table I Mechanical and Thermal properties of PC-EPDM Blends

\begin{tabular}{|c|c|c|c|c|c|c|c|}
\hline \multirow[t]{2}{*}{ S No } & \multirow[t]{2}{*}{ properties } & \multirow[t]{2}{*}{ Unit } & \multirow[t]{2}{*}{$\mathrm{PC}$} & \multicolumn{4}{|c|}{$\mathrm{PC}+\mathrm{EPDM}$} \\
\hline & & & & $5 \%$ & $10 \%$ & $15 \%$ & $20 \%$ \\
\hline 2 & $\begin{array}{l}\text { Flexural } \\
\text { Strength }\end{array}$ & $\mathrm{Kg} / \mathrm{cm}^{2}$ & 571 & 558 & 548 & 492 & 483 \\
\hline 3 & $\begin{array}{l}\text { Impact strength } \\
\text { Izod, notched }\end{array}$ & $\mathrm{Kg} . \mathrm{cm} / \mathrm{cm}$ & 90 & 154 & 160 & 162 & 163.3 \\
\hline 4 & $\begin{array}{c}\text { Melt Flow Index } \\
\text { at } 300^{\circ} \mathrm{C} / 5 \mathrm{~kg} \\
\text { lead }\end{array}$ & $\mathrm{gm} / 10 \mathrm{~min}$ & 10.00 & 10.05 & 10.56 & 11.79 & 11.97 \\
\hline
\end{tabular}

The Tensile strength decreases from $400 \mathrm{Kg} / \mathrm{cm}^{2}$ of PC to 398 and $317 \mathrm{Kg} / \mathrm{cm}^{2}$ as concentration of EPDM increased from 5\% to 20\%. The Flexural strength lowers considerably (Table 1). This is due to the rubbery behavior of EPDM elastomeric segments. Due to the increase in flexibility these mechanical properties were decreased, the impact strength, Izod, notched was increased from $90 \mathrm{Kg} . \mathrm{cm} / \mathrm{cm}$ to $159,160,162 \& 163$ $\mathrm{Kg} . \mathrm{cm} / \mathrm{cm}$ when PC was blended with $5 \%, 10 \%, 15 \%$ \& 20\% EPDM (Fig 1). This is due to the increase in Toughness (and flexibility) of PC-EPDM. Hence PC-EPDM may be useful as products such as helmets with very higher (greater) impact strength.

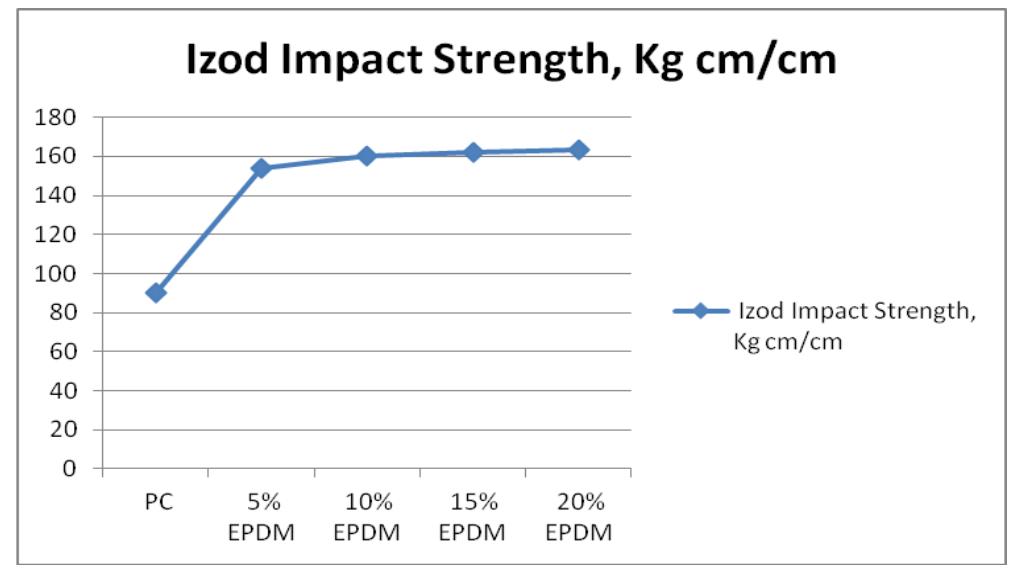

Figure 1 Impact Strength of PC and PC-EPDM blends

The MFI was slightly increased with the addition of EPDM rubber. The electrical properties of PCEPDM are shown in Table 2. The arc resistance of PC is lower about $35 \mathrm{sec}$. It is improved to $97 \mathrm{sec}$ with $20 \%$ EPDM in the blend (fig 2). Hence PC-EPDM blends may be useful as electrical fittings \& plugs with greater electrical resistances than that of PC alone. The volume resistivity and surface resistivity are increased.

Table II Electrical properties of PC-EPDM Blends

\begin{tabular}{|c|c|c|c|c|c|c|c|}
\hline \multirow[t]{2}{*}{ S.No } & \multirow[t]{2}{*}{ properties } & \multirow[t]{2}{*}{ Unit } & \multirow[t]{2}{*}{$\mathrm{PC}$} & \multicolumn{4}{|c|}{ PC-EPDM Blends } \\
\hline & & & & $5 \%$ & $10 \%$ & $15 \%$ & $20 \%$ \\
\hline 1 & $\begin{array}{l}\text { Dielectric } \\
\text { Strength }\end{array}$ & $\mathrm{KV} / \mathrm{mm}$ & 14 & 15.82 & 17.31 & 18.66 & 20.30 \\
\hline 3 & $\begin{array}{c}\text { Surface } \\
\text { Resistivity }\end{array}$ & Ohms/sqcm x $10^{15}$ & 6.26 & 7.16 & 7.66 & 8.16 & 9.15 \\
\hline 4 & Arc Resistance & $\mathrm{Sec}$ & 35 & 39 & 59 & 87 & 97 \\
\hline
\end{tabular}

The Dielectric strength also has improved from $14 \mathrm{KV} / \mathrm{mm}$ to $20 \mathrm{Kv} / \mathrm{mm}$. The water absorption is decreased due to poly olefinic nature of EPDM which has lower WA (Water Absorption). 


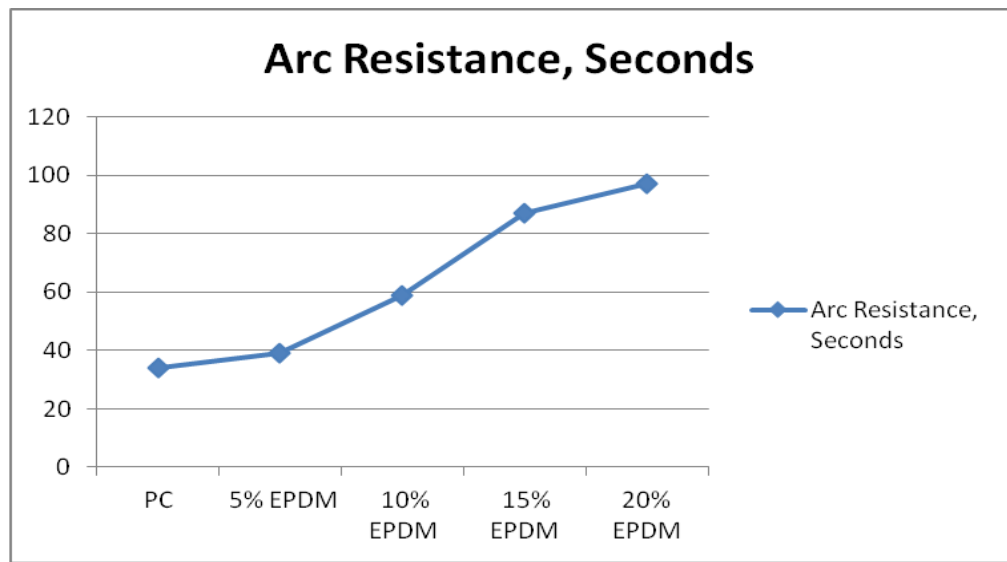

Figure 2 Arc Resistance of PC and PC-EPDM blends

At lower conc. (5-20\%), the EPDM will be miscible with PC. Hence there is a uniform increasing trend in the mechanical, electrical \& thermal properties. This trend shows that the PC/EPDM blend is miscible one $(9,10)$.

\section{Conclusion}

The impact strength was increased to about $200 \%$ when PC was blended with 5-20 wt $\%$ EPDM Rubber. The Tensile strength \& Flexural strength are little lowered by about 10-20\% depending upon the conc of EPDM elastomer. The PC-EPDM blends may be useful in low temperature applications like TPE's(Thermo Plastics Elastomers).

The electrical properties are also improved , particularly the arc resistance was improved by about 250 $300 \%$ when 15-20\% EPDM was blended with PC. The PC-EPDM blends may be suitable for Automotive applications with improved chemical \& oil resistance than PC/ABS blends; And also, may be useful in electrical application with improved Arc resistance.

\section{References}

[1] J.A.Brydson, Plastics materials , ButterWorth Heinemann , $1997,7^{\text {th }}$ Edition , P 562-569

[2] Ibid P299-300

[3] RP Singh , C.K.Das , SK Mustafi, Polymer blends and alloys (An overview) Asian Books Pvt Ltd, NewDelhi,2002,P209-210.

[4] Premamoy Ghosh , Bibha Chahopadhyay, Eurvpene Polymer Journal 32,(8),1996 PP 1015-1021.

[5] Jeroen Oderkerk, Gabriel Groeninckx, Polymer, 43(8),2002 P 2219-2228

[6] As ref (1), page 577-578.

[7] Bala Krishnan S and Neela Kandan NR , Polymer International 45(4) 1998, P 347-352

[8] Annual Book of ASTM Standards Vol 08-01-0.3, USA

[9] B.Kuraiakose , S.K De, " Studies on the melt flow behavior of Thermoplastics elastomers from Poly propylene -natural Rubber blend", Journal of Polymer Engineering and Science, 25(10) 1985 , P630-634.

[10] S.Soundararajan and Subhas C. Shit " Studies on properties of Poly olefins: Poly propylene Copolymer (PPcp) blends with Poly oxy methylenes (POM)", J.Polymer Testing , 20(2001), P313-316. 